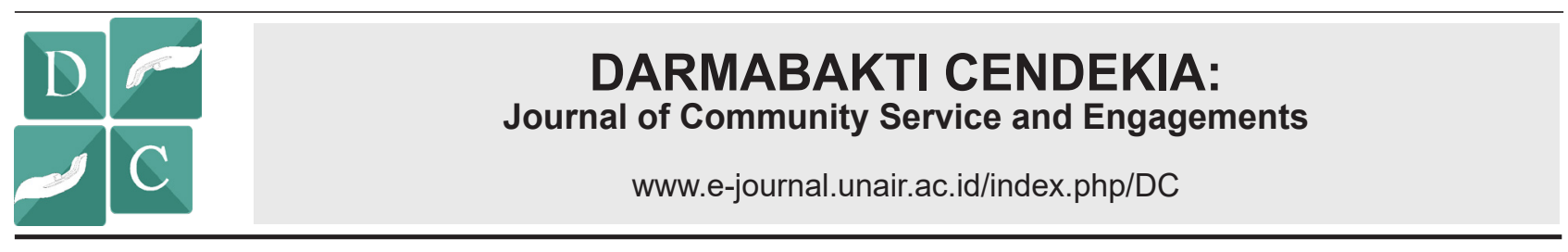

\title{
EDUCATION ON THE RISKS OF USING HAZARDOUS ADDITIVES IN SNACKS FOR STUDENTS AT MARGAHAYU II ELEMENTARY SCHOOL IN BEKASI CITY
}

\author{
EDUKASI RISIKO PENGGUNAAN ZAT ADITIF BERBAHAYA PADA \\ JAJANAN BAGI SISWA SD NEGERI MARGAHAYU II KOTA BEKASI
}

Scope:

Health

\author{
Annisa Amalia ${ }^{*}$, Sari Defi Okzelia ${ }^{1}$, Fajar Amirullah ${ }^{1}$, Ristiana Kusumawinahyu ${ }^{1}$, \\ Dina Wahyu Pratiwi ${ }^{1}$, Siti Mar'atun ${ }^{1}$ \\ ${ }^{1}$ Bachelor of Pharmacy Study Program, Department of Pharmacy, Sekolah Tinggi Ilmu Kesehatan Bani Saleh, Bekasi-Indonesia
}

\begin{abstract}
A B S T R A C T
Background: Food safety and quality studied by BPOM Indonesia in 2008-2011 showed that around $48 \%$ of hazardous substances are found in snacks of elementary school children. Throughout 2012, this percentage increased to 66.7\%. Cases of chemical contamination that are still frequently found are the use of additives such as formaldehyde, borax and rhodamine B. Lack of supervision and education to children causes the possibility of consuming dangerous foods to be large thus increasing the risk to health. Objective: This activity was conducted to improve understanding, knowledge and awareness of the community, especially students about the risk of using hazardous additives in snacks. Method: Stages of community service activities include: (1) Pre-activity; (2) Implementation; and (3) Evaluation. The method used was a combination of community education and demonstration. In the core of the activity, there were three sub-activities implemented. Results: An increase in understanding hazardous additives in snacks for students was achieved. It was known that the sample circulating around school did not contain rhodamine $B$ and borax. Futhermore, students can practice one simple way to implement clean and healthy living. Conclusion: The program provided an increase in understanding and awareness of hazardous additives in snacks for students.
\end{abstract}

\begin{abstract}
A B S T R A K
Latar belakang: Keamanan dan kualitas pangan yang diteliti oleh BPOM tahun 20082011 menunjukkan bahwa sekitar 48\% zat berbahaya terdapat pada jajanan anak sekolah dasar. Sepanjang tahun 2012, persentase ini meningkat hingga 66,7\%. Kasus cemaran kimia yang masih sering ditemui pada makanan jajanan SD adalah penggunaan zat aditif seperti formalin, boraks, dan pewarna rhodamin B. Kurangnya pengawasan dan edukasi bagi anak-anak menyebabkan kemungkinan konsumsi makanan berbahaya menjadi besar sehingga meningkatkan risiko kesehatan. Tujuan: Kegiatan ini dilakukan untuk meningkatkan pemahaman, pengetahuan, dan kesadaran masyarakat, terutama siswa tentang risiko penggunaan bahan tambahan berbahaya dalam pangan jajanan. Metode: Tahapan kegiatan pengabdian masyarakat meliputi: (1) Pra-kegiatan; (2) Implementasi; dan (3) Evaluasi. Metode yang digunakan adalah kombinasi antara pendidikan masyarakat dan demonstrasi. Dalam kegiatan inti, terdapat tiga sub kegiatan yang dilaksanakan. Hasil: Peningkatan pemahaman tentang zat aditif berbahaya pada jajanan bagi siswa telah tercapai. Diketahui bahwa sampel yang beredar di sekitar sekolah tidak mengandung rhodamin B dan boraks. Lebih jauh, siswa dapat mempraktikkan satu cara sederhana untuk menerapkan perilaku hidup bersih dan sehat. Kesimpulan: Program ini memberikan peningkatan dalam pemahaman dan kesadaran tentang zat tambahan berbahaya pada jajanan bagi siswa.
\end{abstract}

\author{
ART I CLE INFO \\ Received 15 July 2020 \\ Revised 16 October 2020 \\ Accepted 10 May 2021 \\ Online 28 June 2021 \\ *Correspondence (Korespondensi): \\ Annisa Amalia \\ E-mail: \\ annissa@stikesbanisaleh.ac.id
}

Keywords:

Additives, Counseling, Elementary Student, Selfawarness, Snacks

Kata kunci:

Zat Aditif; Penyuluhan; Siswa Sekolah Dasar; Kesadaran Diri; Jajanan 


\section{PENDAHULUAN}

Peran Bahan Tambahan Pangan (BTP) menjadi semakin penting sejalan dengan kemajuan teknologi produksi bahan tambahan pangan sintetis (Seprianto et al., 2019). Melalui Permenkes No. 33 Tahun 2012 pemertntah merilis 27 golongan BTP yang diperbolehkan dalam pangan beserta contohnya dan 19 golongan BTP ilegal (dilarang) (Rosyidah et al., 2018; Wahyudi, 2017). Beberapa BTP Ilegal dlantaranya adalah boraks (pengempal yang mengandung logam berat Boron), formalin (pengawet yang digunakan untuk mayat), rhodamin B (pewarna merah pada tekstil), dan methanyl yellow (pewarna kuning pada tekstil) yang saat ini banyak ditambahkan pada makanan. Pengaruh jangka pendek penggunaan bahanbahan ini dapat menimbulkan gelaja-gejala yang sangat umum seperti pusing dan mual. Pengaruh jangka panjang, bahan-bahan ini dapat terakumulasi pada tubuh dan bersifat karsinogenik sehingga menyebabkan penyakit-penyakit seperti kanker dan tumor pada organ tubuh manusia (Purwani \& Muwakhidah, 2016).

Berdasarkan data Dapodik yang diakses pada Januari 2020, diketahui terdapat lebih dari 80 sekolah dasar di Kecamatan Bekasi Timur (Direktorat Jenderal Pendidikan Anak Usia Dini, Pendidikan Dasar, dan Pendidikan Menengah, 2020a). Hampir di sepanjang Jalan R.A Kartini yang berdekatan dengan STIKES Bani Saleh terdapat bangunan SD. Kenyataan tentang banyaknya jumlah sekolah di daerah ini menjadikannya sebagai peluang bisnis bagi pedagang kaki lima untuk menjual pangan jajanan kepada siswa. Hal ini merupakan salah satu penyebab meningkatnya budaya jajan.

Makanan jajanan adalah makanan dan minuman yang dipersiapkan dan dijual oleh pedagang kaki lima di jalanan dan di tempattempat keramaian umum lain yang langsung dimakan atau dikonsumsi tanpa pengolahan atau persiapan lebih lanjut (S. Eko \& Hartari, 2019). Kebiasaan jajan di sekolah sangat bermanfaat jika makanan yang dibeli sudah memenuhi syaratsyarat kesehatan, sehingga dapat melengkapi atau menambah kebutuhan gizi anak. Disamping itu, hal ini juga dapat membantu mencegah kekosongan lambung, karena setiap 3-4 jam sesudah makan, anak akan merasa lapar (Intan et al., 2020). Kurangnya pengawasan dan edukasi menyebabkan kemungkinan konsumsi makanan berbahaya menjadi besar sehingga meningkatkan risiko bagi kesehatan. Keamanan dan kualitas pangan yang diteliti oleh BPOM tahun 2008-2011 menunjukkan bahwa sekitar $48 \%$ zat berbahaya terdapat pada jajanan anak sekolah dasar. Sepanjang tahun 2012, persentase ini meningkat hingga 66,7\%(Paratmanitya \& Aprilia, 2016). Kasus cemaran kimia yang masih sering ditemui pada makanan jajanan SD adalah penggunaan zat aditif seperti formalin, boraks, dan pewarna rhodamin B. Zat aditif berbahaya ini seringkali diberikan untuk meningkatkan warna, bau, rasa, dan tekstur sehingga menimbulkan selera makan bagi anak.

Sekolah Dasar Negeri (SDN) Margahayu II merupakan sekolah dasar milik pemerintah yang berlokasi di Jl. R.A. Kartini RT 003 RW 005 Margahayu Kecamatan Bekasi Timur Kota Bekasi. SDN Margahayu II memiliki ruang kelas sebanyak 6 kelas, juga memiliki ruang perpustakaan dan sanitasi siswa. SDN Margahayu II memiliki 14 orang guru dengan jumlah total siswa sebanyak 454 orang (Direktorat Jenderal Pendidikan Anak Usia DInı, Pendidikan Dasar, dan Pendidikan Menengah, 2020b).

Di sekitar sekolah banyak diperjualbelikan makanan (jajanan) anak-anak seperti cimol, cilok, sate lilit, sempol, aneka keripik, aneka gorengan dengan bumbu tabur, saus, dan aneka minuman. Kisaran harga di antara Rp 500,00 - Rp 5.000,00. Anak-anak SDN Margahayu II gemar untuk mengkonsumsi jajanan karena ketersediaannya yang banyak dan tampilan jajanan yang beraneka warna, bentuk, rasa, dan aroma yang menarik. Terkadang hal ini yang membuat anak-anak kurang mempedulikan kesehatan dan kualitas jajanan.

Konsumsi zat aditif berbahaya sesekali umumnya tidak memberikan efek signifikan bagi kesehatan. Namun, jangka panjang penggunaan bahan-bahan ini dapat memicu gangguan tumbuh kembang bagi anak, kerusakan ginjal, hingga kanker. Kasus ini belum pernah terjadi di lingkungan SDN Margahayu II. Namun, banyaknya jajanan yang beredar di sekitar sekolah dapat memunculkan kecenderungan timbulnya kasus.

Kegiatan edukasi untuk memahami risiko bahan tambahan pangan berbahaya bagi kesehatan pada jajanan dan cara sederhana untuk mengenalinya merupakan suatu langkah preventif yang dapat dilakukan. Hal ini juga secara tidak langsung dapat meningkatkan kesadaran budaya sehat bagi anak melalui pemilihan jajanan bergizi.

\section{METODE}

Tahapan kegiatan pengabdian masyarakat yang dilakukan mencakup: (1) Pra kegiatan; (2) Pelaksanaan kegiatan; dan (3) Evaluasi. Tahapan ini diadopsi dari kegiatan serupa sebelumnya yang dilakukan oleh Intan et al. (2020), namun terdapat beberapa bagian yang dimodifikasi sesuai kebutuhan mitra yang digambarkan pada Cambar1

Pra kegiatan dikemas dalam empat tahapan 
utama yang ditargetkan untuk membentuk kerjasama dengan mitra hingga merumuskan teknis kegiatan dan mempersiapkan perlengkapan yang dibutuhkan.

Pelaksanaan kegiatan mengadaptasi Metode Pendidikan Masyarakat yang melibatkan edukasi atau penyuluhan. Menurut Gary Dessler dalam Rosita \& Sophia (2019), langkahlangkah penyuluhan yang baik menjadi penentu keberhasilan ditanamkannya pengetahuan maupun keterampilan tertentu. Sasaran kegiatan adalah 50-75 orang yang dipetakan langsung bersama mediator pihak mitra. Penyuluhan ditujukan untuk meningkatkan pemahaman serta kesadaran peserta akan risiko penggunaan bahan tambahan (zat aditif) berbahaya pada makanan, yaitu pangan jajanan SD. Selain penyuluhan, kegiatan ini dikemas dengan pelatihan langsung bagi peserta, yaitu berupa demonstrasi atau percontohan untuk mendeteksi keberadaan beberapa zat aditif berbahaya secara organoleptis, kimiawi, maupun menggunakan rapid test kit. Tidak hanya dicontohkan, kegiatan pendeteksian dirancang agar melibatkan secara langsung partisipasi peserta (semi-praktik) untuk memberikan pengalaman tersendiri dalam mendeteksi bahan-bahan yang diujikan. Sosialisasi Perilaku Hidup Bersih dan Sehat (PHBS) pada penghujung pelaksanaan kegiatan dilakukan sebagai langkah persuasif untuk meningkatkan budaya sehat yang dimulai dari langkah kecil pada diri sendiri.

Kegiatan evaluasi dilakukan untuk mengukur ketercapaian tujuan kegiatan melalui pemahaman peserta yang dilakukan secara seri per kegiatan. Kegiatan evaluasi juga dilakukan pada ranah kemitraan dan kinerja tim untuk meningkatkan jalinan kerjasama antara pihak institusi dan pihak mitra. Evaluasi kinerja tim dilakukan untuk menjaga mutu dan meningkatkan kualitas penyelenggaraan kegiatan.

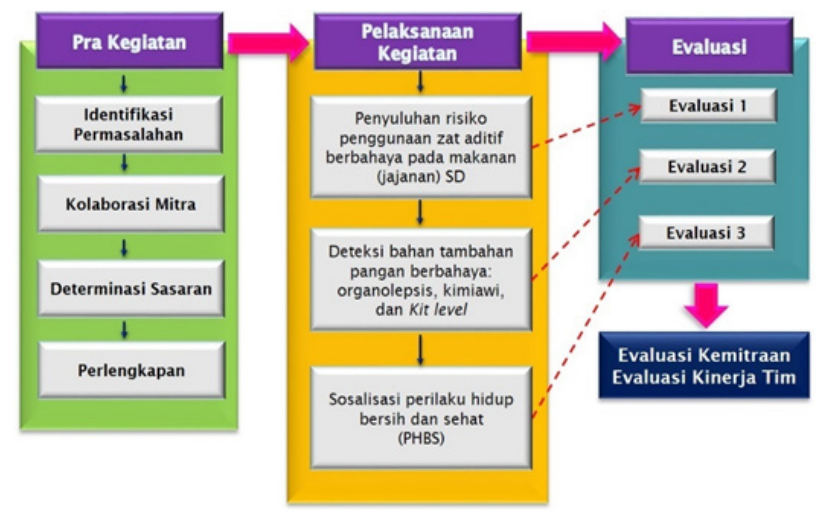

Gambar 1. Skema kegiatan pengabdian masyarakat

\section{HASIL DAN PEMBAHASAN}

Kolaborasi dengan mitra diawali dengan melakukan studi pendahuluan tentang SDN Margahayu II yang selanjutnya mengidentifikasi kelompok sasaran program. Ketua tim PKM mengajukan proposal yang ditujukan kepada kepala Direktorat Penelitian dan Pengabdian Masyarakat (DPPM) STIKES Bani Saleh yang dilanjutkan dengan penugasan yang ditujukan ke Kepala Sekolah SDN Margahayu II. Tim PKM bersama dengan pihak sekolah menetapkan kelompok sasaran kegiatan secara bersama yaitu siswa/i kelas 5. Siswa/i ini dipilih berdasarkan faktor psikologis dan ketersediaan waktu. Siswa/i kelas 5 dinilai sudah berada dalam kategori mampu menerima informasi dan mengolahnya menjadi bahan pembelajaran. Tim PKM bersama dengan guru kelas yang menjadi kelompok sasaran yaitu Wali Kelas 5 berkoordinasi tentang teknis pelaksanaan kegiatan PKM. Tim PKM diberikan waktu untuk memberikan penyuluhan dan melakukan langkah mudah dalam pendeteksian bahan tambahan pangan berbahaya yang terkandung dalam jajanan yang beredar di sekitar SDN Margahayu II pada hari Senin, 27 Januari 2020. Target kegiatan ini adalah siswa/i kelas 5 yang terdiri atas 2 rombongan belajar yaitu $A$ dan B dengan jumlah total 50-70 siswa (Gambar 2).

Untuk keberlangsungan acara, berbagai perlengkapan disediakan dan konsep acara dirancang sedemikian rupa sehingga siswa dapat memahami dengan mudah materi yang diberikan. Kegiatan ini merupakan kegiatan kolaborasi dosen dan mahasiswa STIKES Bani Saleh. Sebanyak 3 dosen masing-masing akan memimpin sesi kegiatan dan mahasiswa berperan sebagai pendamping peserta dan pelaksana teknis kegiatan.

Kegiatan penyuluhan risiko penggunaan zat aditif berbahaya pada pangan jajanan dibuat dalam presentasi interaktif dengan mengutip sumbersumber yang valid dan relevan. Presentasi disajikan dengan tampilan yang menarik dan menggunakan gambar-gambar yang dekat dengan kehidupan sehari-hari. Adapun gambaran tentang bahan tambahan pangan berbahaya mengutip sumber Direktorat Surveilan dan Penyuluhan Keamanan Pangan Deputi Bidang Pengawasan Keamanan Pangan dan Bahan Berbahaya Badan Pengawas Obat dan Makanan (BPOM) dan Promosi Kesehatan Gerakan Masyarakat (Germas) Hidup Sehat Kementerian Kesehatan Republik Indonesia. Beberapa di antaranya adalah: "Ayo kenali bahan berbahaya pada makanan dan minuman"; "Waspada terhadap 3 bahaya pada pangan"; "Hindari jajan sembarangan"; dan "Pilih jajanan sehat" (Gambar 3) (Direktorat Pencegahan dan 


Pengendalian Penyakit Iidak Menular Direktorat
Jenderal Pencegahan dan Pengendalian Penyakit,
2018a, 2018b; Direktorat Promosi Kesehatan dan
Pemberdayaan Masyarakat, 2020; Direktorat
Surveilan dan Penyuluhan Keamanan Pangan
Deputi Bidang Pengawasan Keamanan Pangan
dan Bahan Berbahaya, 2016).

Kegiatan deteksi bahan pangan berbahaya dikemas dalam bentuk kegiatan demonstrasi dan semi-praktikum. Beberapa bahan dikenalkan secara organoleptis meliputi rasa, bau, dan warna. Zat pewarna berbahaya memiliki warna yang kurang alami (mencolok), rasa yang umumnya lebih pahit, dan meninggalkan bekas warna pada tangan jika dipegang. Zat pengawet seperti formalin umumnya dapat memberikan tekstur yang lebih kenyal pada makanan. Penggunaan formalin juga dipelajari secara kimiawi menggunakan kertas kunyit atau yang dikenal sebagai kertas tumerik (Ma'ruf, et al., 2017). Pembuatan deteksi boraks kertas tumerik pada kegiatan PKM ini mengikuti metode yang telah dilakukan sebelumny (Hartati, 2017) dengan memodifikasi ukuran kertas yang dihasilkan. Kertas turmerik yang dihasilkan mempunyai warna kuning pada kertas saring yang berasal dari ekstrak kunyit yang disarikan (Gambar 4). Menurut Halim dalam Suseno (2019), jika sampel mengandung boraks maka akan terjadi perubahan warna pada kertas turmerik dari kuning menjadi coklat kemerahan. Warna coklat kemerahan ini merupakan warna dari kompleks boron-kurkumin yaitu rososianin. Pengenalan formalin dengan cara ini dilakukan agar siswa dapat dengan mudah melakukan pendeteksian di rumah karena menggunakan bahan-bahan yang mudah ditemukan pada kehidupan sehari-hari. Selain secara organoleptis dan kimiawi, deteksi terhadap bahan juga dilakukan menggunakan rapid test kit rhodamin kualitatif 50 test yang didapatkan dari distributor Labstest. Kemasan Rhodamin B Test Kit terdiri dari dua larutan pereaksi atau reagen, yaitu reagen $A$ yang berisi larutan pereaksi $\mathrm{SbCl}_{5}$ (Stibium Klorida) dalam $\mathrm{HCl} 5 \mathrm{~N}$ dan reagen $\mathrm{B}$ yang berisi larutan pereaksi toluena (Metil Benzena). Suatu bahan makanan yang positif mengandung Rhodamin B ditandai dengan tidak menghilangnya warna merah larutan saat penambahan reagen A yang dilakukan. Warna merah kembali muncul dengan intensitas warna yang semakin menguat hingga menjadi warna ungu kemerahan saat penambahan reagen $B$ (Andayani, 2013).

Kegiatan sosialisasi perilaku hidup bersih dan sehat (PHBS) dirancang untuk ditampilkan terakhir untuk mengemas kegiatan lebih menarik bagi siswa dengan menggunakan media lagu. Materi yang disiapkan adalah mengenali 7 langkah mencuci tangan yang baik dan benar yang merujuk pada kegiatan Menteri Kesehatan, Kepala Pusat Kesehatan, TNI dan Kepala Pusdokkes POLRI di Pengungsian Gelanggang Remaja Cengkareng.

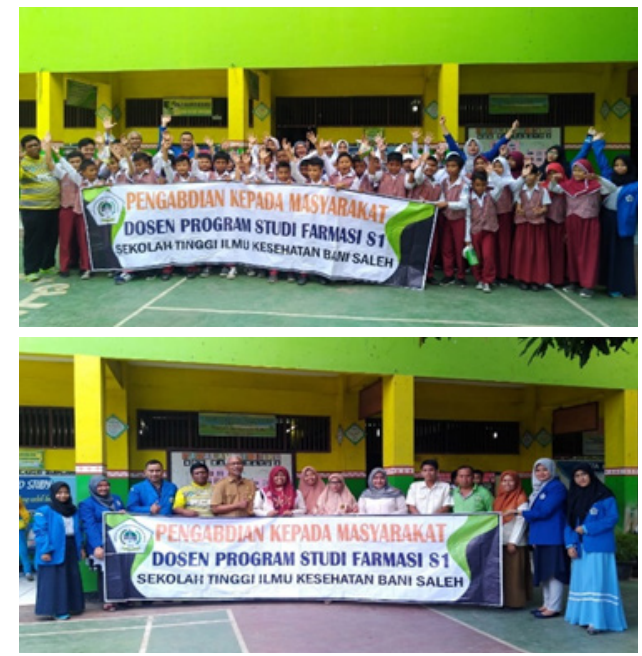

Gambar 2. Dokumentasi bersama peserta dan guru SDN Margahayu II

Kegiatan ini dihadiri oleh 62 peserta yang berasal dari 51 siswa/i kelas 5 rombongan belajar A dan B, 5 orang pihak sekolah SDN Margahayu II, dan 6 orang tim pengabdian masyarakat STIKES Bani Saleh. Pemaparan materi tentang "Risiko Penggunaan Zat Aditif Berbahaya pada Jajanan SD" disampaikan oleh Pemateri 1. Penyuluhan ini dilakukan secara interaktif yang melibatkan seluruh siswa/i. Di akhir sesi dilakukan tanya jawab dan diskusi untuk melihat pemahaman siswa/i tentang materi yang diberikan. Berdasarkan tanya jawab dan diskusi tersebut, diketahui bahwa siswa/i sudah memahami risiko penggunaan zat aditif berbahaya pada makanan berikut contohnya (Gambar 3).

Pengujian secara langsung keberadaan rhodamin B dan boraks dalam bumbu tabur, bakso dan cilok dipimpin oleh Pemateri 2. Sebelumnya tim PKM telah membeli dan menyiapkan sampel yang akan diuji pada pedagang jajanan di sekitar SDN Margahayu II. Pendeteksian ini dilakukan dengan metode praktikum langsung oleh beberapa siswa/i yang sebelumnya telah dicontohkan dan diperlihatkan video edukasinya. Siswa/i dengan sangat antusias ingin melakukan praktikum ini, akan tetapi karena keterbatasan waktu, hanya beberapa orang saja yang dapat mempraktikkan. Di akhir sesi, dilakukan tanya jawab, diskusi dan diketahui bahwa siswa/i sudah bisa mempraktikkan cara mendeteksi rhodamin B dan boraks dalam jajanan. Tim PKM juga memberikan cara mudah membuat pereaksi dan mempraktikkan di rumah sehingga siswa/i yang tidak sempat mempraktikkan langsung bisa 
mempraktikkan sendiri di rumah untuk analisis boraks menggunakan kertas tumerik (Gambar 4).
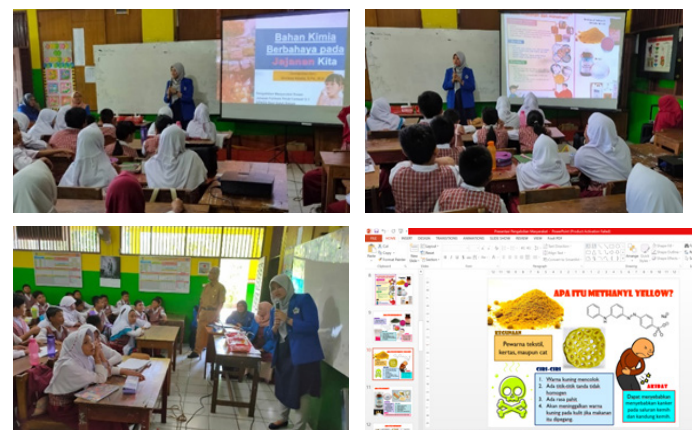

Gambar 3. Kegiatan penyuluhan risiko penggunaan zat aditif berbahaya
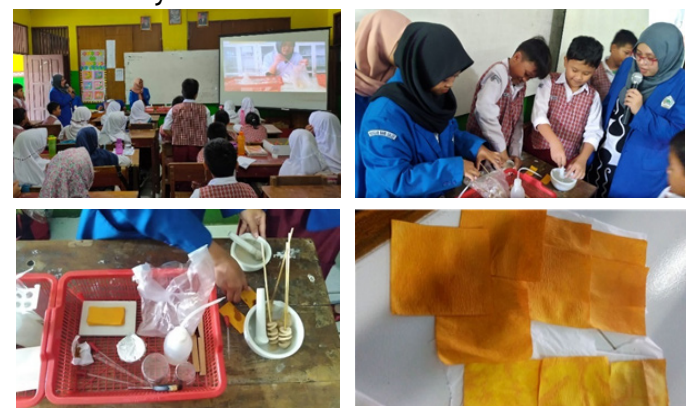

Gambar 4. Kegiatan pendeteksian zat aditif berbahaya pada pangan jajanan SD

Kegiatan sosialisasi tentang hidup bersih dan sehat dengan mencuci tangan disampaikan oleh Pemateri 3. Kegiatan ini diawali dengan penyampaian materi tentang hidup bersih dan ditutup dengan bernyanyi bersama tentang langkah cuci tangan yang baik. Di akhir sesi, siswa/i sudah bisa mempraktikkan 7 langkah mencuci tangan yang baik dan benar (Gambar 5).

Kegiatan evaluasi dilakukan per sesi untuk menangkap pemahaman siswa tentang materi yang diberikan. Evaluasi dilakukan melalui tanya jawab kepada siswa. Antusiasme siswa terlihat di setiap pertanyaan yang diajukan. Beberapa siswa dipilih untuk menjawab pertanyaan. Jawaban siswa dan sorak sorai siswa menjadi indikator pemahaman tentang materi yang diberikan. Terdapat peningkatan pemahaman siswa terhadap risiko penggunaan bahan tambahan pangan berbahaya dari yang sebelumnya belum diketahui. Reward diberikan kepada siswa yang telah berani maju dan menjawab pertanyaan pada sesi evaluasi

\section{(Gambar 6).}

Kegiatan evaluasi juga dilakukan dalam tingkat kemitraan dan kinerja tim. Partisipasi mitra yakni aktif dalam memfasilitasi dan mengarahkan siswa/i ke ruang kelas dan menjamin siswa/i untuk tetap kondusif. Pihak SDN Margahayu II sangat kolaboratif dalam memfasilitasi kegiatan ini dan meminta untuk tetap menjalin kerjasama yang baik demi kelanjutan kegiatan ini.
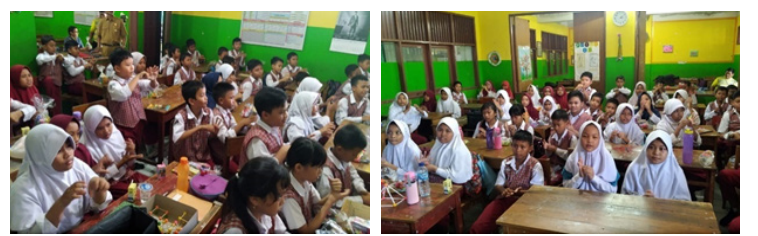

Gambar 5. Kegiatan sosialisasi Perilaku Hidup Bersih dan Sehat (PHBS)
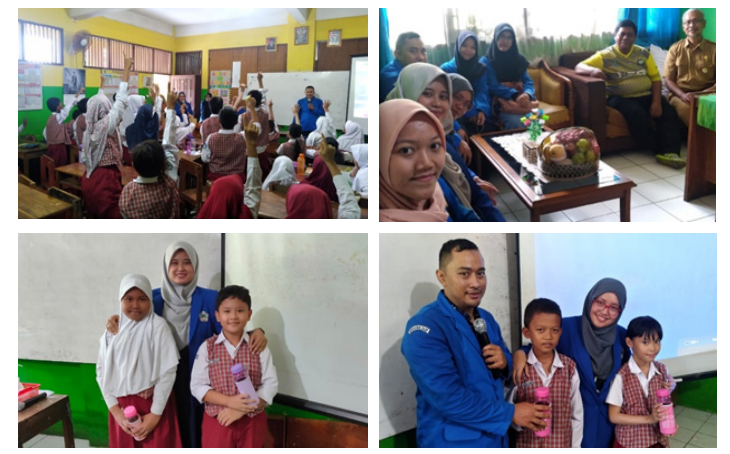

Gambar 6. Kegiatan evaluasi dan rewarding peserta

\section{KESIMPULAN DAN SARAN}

Kegiatan pengabdian masyarakat yang telah dilakukan di SDN Margahayu II telah memberikan peningkatan pemahaman dan kesadaran tentang bahan tambahan berbahaya pada pangan jajanan SD. Pada kegiatan pendeteksian bahan tambahan pangan berbahaya pada Jajanan SD dapat disimpulkan bahwa sampel bumbu tabur, bakso dan cilok yang beredar di sekitar SDN Margahayu II tidak mengandung rhodamin B dan boraks. Siswa/i SDN Margahayu II telah memahami tentang bahan tambahan pangan berbahaya antara lain rhodamin B, methanyl yellow, boraks, dan formalin. Selain itu siswa/i bisa mendeteksi keberadaan rhodamin B dan boraks dalam jajanan SD dan bisa mempraktikkan sendiri cara mendeteksi boraks di rumah masing-masing. Pola hidup bersih dan sehat bisa diterapkan secara mandiri dimulai dengan memahami 7 langkah mencuci tangan yang benar.

\section{UCAPAN TERIMA KASIH}

Kegiatan edukasi penggunaan zat aditif berbahaya pangan jajanan SD di SDN Margahayu II didanai oleh Direktorat Penelitian dan Pengabdian kepada Masyarakat (DPPM) STIKES Bani Saleh Bekasi. Pelatihan ini juga bekerjasama dengan SDN Margahayu II Kota Bekasi sebagai mitra pelaksanaan kegiatan Pengabdian Kepada Masyarakat (PKM). Penulis menyatakan tidak ada konflik kepentingan dengan pihak-pihak yang terkait dalam kegiatan pengabdian kepada masyarakat ini. 


\section{DAFTAR PUSTAKA}

Andayani, D. 2013. Analisis Zat Pewarna Rhodamin B pada Gula Kapas Merah yang Dijual di Kota Mataram Tahun 2013. Jurnal Ilmu Kesehatan dan Farmasi. Vol. 1(1). Pp. 8-11.

Direktorat Jenderal Pendidikan Anak Usia Dini Pendidikan Dasar dan Pendidikan Menengah, Kementerian Pendidikan dan Kebudayaan Republik Indonesia. 2020a. Data Pokok Pendidikan Profil Sekolah SDN Margahayu II. Available from: https://dapo.kemdikbud. go.id/sekolah/25FA3394D93456FAD6DE. Diakses: 6 Januari 2020.

Direktorat Jenderal Pendidikan Anak Usia Dini Pendidikan Dasar dan Pendidikan Menengah, Kementerian Pendidikan dan Kebudayaan Republik Indonesia. 2020b. Data Pokok Pendidikan Jumlah Sekolah di Kecamatan Bekasi Timur. Available from: https://dapo. kemdikbud.go.id/sp/2/026500. Diakses: 6 Januari 2020.

Direktorat Pencegahan dan Pengendalian Penyakit Tidak Menular Direktorat Jenderal Pencegahan dan Pengendalian Penyakit, Kementerian Kesehatan Republik Indonesia. 2018a. Pilih Jajanan Sehat! Jajanan Harus Bersih, Aman dan Bergizi. Available from: http://p2ptm.kemkes.go.id/infographicp2ptm/hipertensi-penyakit-jantung-danpembuluh-darah/page/22/pilih-jajanan-sehatjajanan-harus-bersih-aman-dan-bergizi. Diakses: 6 Januari 2020.

Direktorat Pencegahan dan Pengendalian Penyakit Tidak Menular Direktorat Jenderal Pencegahan dan Pengendalian Penyakit, Kementerian Kesehatan Republik Indonesia. 2018b. Waspada Jajanan yang Kurang Sehat. Available from: http://p2ptm.kemkes.go.id/ preview/infografhic/waspada-jajanan-yangkurang-sehat?hcb=1. Diakses: 6 Januari 2020.

Direktorat Promosi Kesehatan dan Pemberdayaan Masyarakat, Kementerian Kesehatan Republik Indonesia. 2020. Video ILM Cuci Tangan Pakai Sabun (CTPS) Minimal 20 Detik. Available from: https://promkes.kemkes.go.id/videoilm-cuci-tangan-pakai-sabun-ctps-minimal-20detik. Diakses: 6 Januari 2020.

Direktorat Surveilan dan Penyuluhan Keamanan Pangan Deputi Bidang Pengawasan Keamanan Pangan dan Bahan Berbahaya, Badan Pengawasan Obat dan Makanan Republik Indonesia. 2016. Ayo Kenali Bahan Berbahaya pada Makanan dan Minuman. Available from: https://klubpompi.pom.go.id. Diakses: 6 Januari 2020.

Hartati, F. K. 2017. Analisis Boraks Dengan Cepat, Mudah dan Murah. Jurnal Teknologi Proses dan Inovasi Industri Vol. 2(1). Pp. 33-37.

Intan, T., Handayani, V. T., \& Hasanah, F. 2020. Edukasi Budaya Jajan Sehat Pada Siswa-Siswi Sdn Jatinangor (Analisis Situasional Dan Rencana Solusi). Jurdimas Vol. 3(1). Pp. 31-38.

Kementerian Kesehatan Republik Indonesia. 2012. Peraturan Menteri Kesehatan Republik Indonesia Nomor 33 Tahun 2012 tentang Bahan Tambahan Pangan. Jakarta: Kementerian Kesehatan Republik Indonesia.

Ma'ruf, H., Sangi, M.S., \& Wuntu, A.D. 2017. Analisis Kandungan Formalin dan Boraks pada Ikan Asin dan Tahu dari Pasar Pinasungkulan Manado dan Pasar Beriman Tomohon. Jurnal MIPA UNSRAT Vol. 6(2). Pp. 24-28.

Paratmanitya, Y., \& Aprilia, V. 2016. Kandungan bahan tambahan pangan berbahaya pada makanan jajanan anak sekolah dasar di Kabupaten Bantul. Jurnal Gizi dan Dietetik Indonesia Vol. 4(1). Pp. 49-55.

Purwani, E., \& Muwakhidah, M. 2016. Peningkatan Pengetahuan Anak SD melalui Edukasi Gizi tentang Makanan Jajanan Sehat dan Gizi Seimbang dengan Media Buku Cerita Bergambar di SD Tiyaran 01 dan 03 Sukoharjo. WARTA LPM Vol. 19(2). Pp. 105-109.

Rosita, B., \& Sophia, A. 2019. Penyuluhan Kesehatan Bahaya Makanan Yang Mengandung Zat Kimia Pada Murid Sdn 06 Balai Talang Kecamatan Guguak Kabupaten 50 Kota Jurnal Abdimas Kesehatan Perintis. Jurnal Abdimas Kesehatan Perintis Vol. 1(1). Pp. 31-34.

Rosyidah, A., et al. 2018. Identifikasi Boraks, Formalin Serta Pewarna Beracun Dan Berbahaya Menuju Produk Makanan Sehat Dan Higienis. Prosiding Seminar Nasional Teknologi dan Perubahan (SEMATEKSOS) 3; Surabaya, Indonesia. Pp. 253-258.

S. Eko Y.E., \& Hartari, A. 2019. Penyuluhan Keamanan Pangan Jajanan anak Sekolah Siswa. Seminar Nasional Pengabdian Masyarakat Universitas Terbuka.

Seprianto, S., Hasibuan, M. P., \& Effendi, D. I. 2019. Pelatihan Deteksi Adanya Formalin, Boraks, dan Pewarna Berbahaya Dalam Makanan Serta Penyuluhan Bahayanya Bagi Kesehatan Masyarakat Desa Meurandeh Dayah Kota Langsa. MARTABEL: Jurnal Pegabdian Masyarakat Vol. 2(2). Pp. 21-25.

Suseno, D. 2019. Analisis Kualitatif dan Kuantitatif Kandungan Boraks Pada Bakso Menggunakan Kertas Turmerik, FT - IR Spektrometer dan Spektrofotometer UV -Vis. Indonesia Journal of Halal Vol. 2(1). Pp. 1-9.

Wahyudi, J. 2017. Mengenali bahan tambahan pangan berbahaya: ulasan identifying hazardous materials for food additive: a review. Jurnal Litbang Vol. 13(1). Pp. 3-12. 